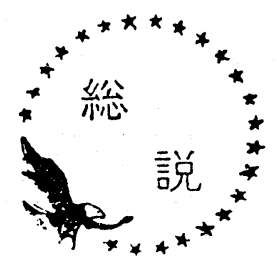

\section{1. 緒言}

LNG の低公害燃料としての優越性については，す でに多くの検討が行なわれ，また1969年から東京瓦斯 根岸工場に導入を開始されたプロゼクトによって実証 されたということができる。この燃料も他の然料と同 様に輸入後消費されるまで貯蔵しなければならない が，この燃料の特徵である非常な低温のために，他の 燃料よりも多くの配慮が必要である。事実, LNG 利 用計画の初期段階で1944年オハイオ州クリーブランド で，タンク材料の低温脆性破壊によって流出したガス に自動車の排気から引火して133名の人命が失われ $た^{1)}$ 。その後タンクの材料と構造は改善を重ね, 今日 では世界の LNG 貯蔵タンクの主流は地上 2 重殼型式 となり, 平常時の安全性については完・゚きに近い構造 が完成されたといらことができる。しかしながら地 震, 台風などの自然災害が多い上に, 人口過密のわが 国にこれをこのまま導入して安全かといらことになる と, かなり問題があり, 東京瓦斯, 大阪瓦斯などでさ らに安全度の高い貯蔵方法である地下タンクが研究開 発されつつあることは, 企業者の姿勢として当然とは いえ誠に喜ばしいことである。

地下タンクの最も大きい特長は地震その他の災害で タンクが破壊しても, LNG が水で置換されない限り は地表面に LNG があふれ出すことはなく, たとえば 引火しても火災の範囲がきわめて限定されることであ る。また, あとで述べるよらに貯液後ある時間が経過 すればタンク周囲に堅固な凍土層ができて, このため に地震による破壊が起こっても地下水または海水と置 換される可能性もきわめて少ないことが予測される。 このほか地下タンクの長所としては, ダイクの必要が ないためにタンク間の間隔を小さくすることができる こと, 航空機の衝突の機会が少ないこと, 巨大な構造 物が地上にそそり立つことがないので付近居住者に対 する威圧感がないこと，などが挙げられる。このよう に地下タンクは自然災害に対する安全性の面からみれ ば，地下タンクに比較して圧倒的な優位にあることは 明らかであるが，さて地下タンクを実際に計画しよう
とすれば，かなり多くの技術的問題点が包蔵されてい ることがわかる。

地下タンクの問題点を大別すると次の二つになる。 一つは地下に大きくしかも深い穴を掘って, その中に タンク軀体を建設するといら技術的な困難である。わ が国では鉄道, 鉱山, 橋梁, 道路, 地下鉄構築のため に，優れた技術が導入または開発され幾多の土木技術 的な難題が克服されてきたとはいうものの, 地下タン クに必要な直径 $40 \mathrm{~m}$ 以上, 深さ $40 \mathrm{~m}$ 以上というような 大きな穴を大都市周辺の軟弱地盤中に安全に掘削した 例は非常に数が少なく, 未経験工事といっても過言で はない。他の一つは, 地下タンク建設時の問題が解決 して, 地下タンクが完成して貯液を開始した後に, 周 囲地盤が凍結することによって発生してくる諸問題で ある。著者らは数年前からこの問題に着目し, 著者ら の十数年来の人工地盤凍結の経験を生かして, 主とし て理論面からこの問題の検討を行なってきた。

本稿は著者らが地下タンクの貯液後に発生する問題 点についての総合的な報告をしようとするものである が, 既述のごとく理論を主としたもので, 確実な実験 的裏付けのあるものではない。したがって本論文は問 題点の所在と解明の程度を指摘したものと解釈してい ただきたい。実験的裹付けについては現在進行中で, 近い将来に理論と比較検討して公表できるものと期待 している。

\section{LNG 地下タンク周囲地盤の凍結範囲}

現在実存している地下タンクは, 図 1 に示すような 短筒形のものが大部分である。このようなタンクに $\mathrm{LNG}$ を貯めると, $-160^{\circ} \mathrm{C}$ という非常な低温のため に，時間の経過に伴って周囲の地盤が凍っていくこと になる。周囲地盤が凍結すると, タンクそのものが全 体として頑丈なものとなり地震に対して強くなるとい ら利点がある反面, 後節で述べるように, 凍結膨張に よって起こる地盤内の応力増加や変位によって, タン ク周囲にある構造物に影響を与えたり, タンク自体が 破壊の危険にさらされることさえ起こりうる。そこで 著者らは, クールダウン後にタンク周辺の地盤がどの 


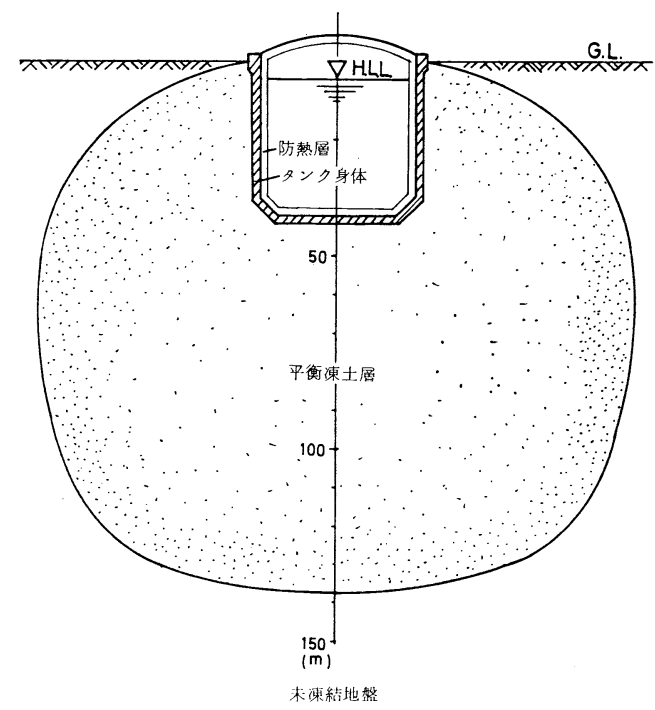

図 $150,000 \mathrm{k} l \mathrm{LNG}$ 地下タンクによる平衡凍土 (防熱厚: $15 \mathrm{~cm}, \theta_{\mathrm{G}}: 16^{\circ} \mathrm{C}, \theta_{\mathrm{C}}:-160^{\circ} \mathrm{C}$, P: 0.6 )
ような経過で凍っていくかを解析した ${ }^{23)}$ 。文献2) は 地中哚く地表面からの太陽熱の影響がない場合を解析 したもので, 文献 3) は図 1 亿示すような実際のタン クに近い状態のものを解析しているが，両者共にかな り大胆な仮定のもとに解析が行なわれているので, 実 験と比較する必要があった。

そこで最近公表された実験結果 (文献 ${ }^{4), 5)}$ ) と比較し たところ，かなりの良好な一致がみられた。したがっ て上記理論解析は地盤, 軀体, 防熱材の熱的諸常数の 選定をあやまらなければ， $\pm 20 \%$ 程度の誤差で実験と 一致することがわかった。そこでこれらの理論計算の 結果を概説すると次のようになる。

(1) LNG を貯めてから時間が経過すると, タンク のまわりの凍土は図 2 に示すよらにだんだん成長し， 無限に時間が経過すると, 図 1 に示すよらなこれ以上 凍土の成長しない平衡状態に到達する。平衡状態にな るまでの時間は, 図 1 亿示すような直径 $40 \mathrm{~m}$ 程度の夕 ンクでは, 約 15,000 年程度と推定できる。

(2) タンク周囲の凍土成長速度を決定する因子は,

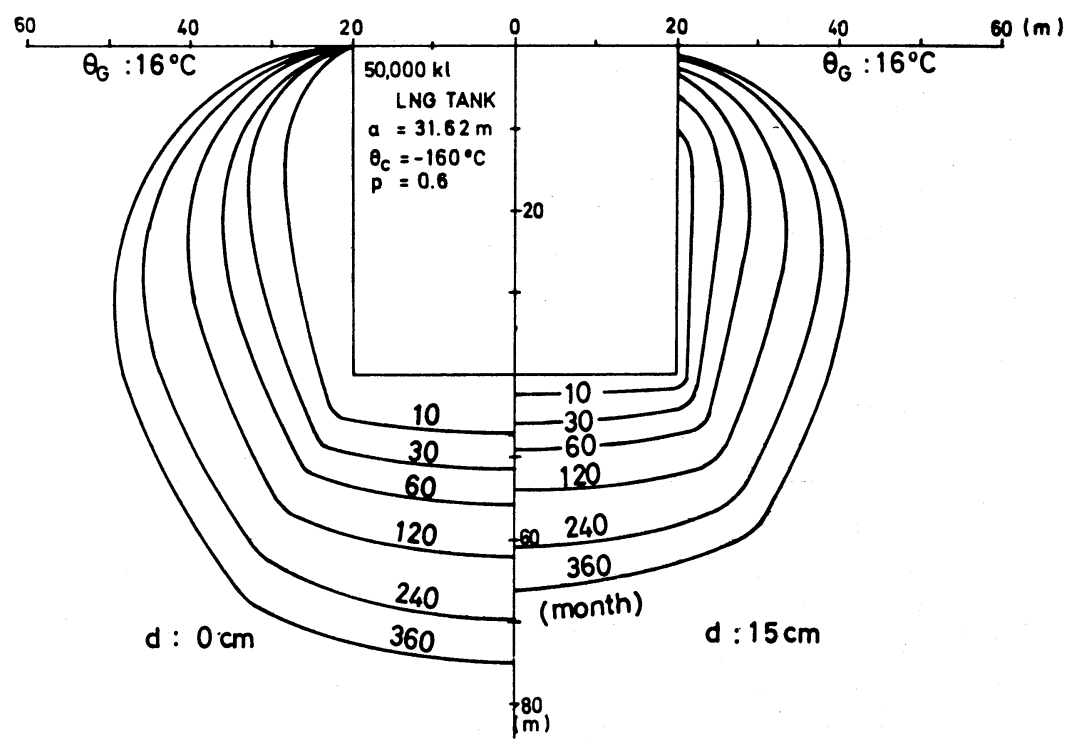

図 $250,000 \mathrm{k} l \mathrm{LNG}$ 地下タンク周囲の地盤の凍結進行

防熱層の熱貫流係数, 地中温度, タンクの直径, 地盤 の容積含水率であるが，これらのらち最も影響度の大 きいものは, 図 2 に示寸ように防熱層の熱貫流係数で ある。 5 項で述べるようにタンクの周囲の地盤の凍結 膨張率が大きいときには, このために起こってくる周 囲構造物やタンク躯体に及ぼす力学的影響が大きいの
で，理想的には防熱層を厚くして周囲の地盤が凍結し ないようにすればよいが，ポリウレタンフォームのよ うな優れた防熱材を使用しても, タンク半径の $1 / 4$ 程 度の厚みの防熱層をつくらないとこの目的を達しえな いことがわかった。たとえば直径 $40 \mathrm{~m}$, 深さ $40 \mathrm{~m}$, 内 容積 $50,000 \mathrm{~m}^{3}$ 程度のタンクでは約 $5 \mathrm{~m}$ の厚みの防熱 
層が必要で，もしこのような防熱層をもつタンクがで きたとしても，防熱層のために膨大な費用がかかるう えに, 肝じんの貯蔵容積が非常に減ってしまう。した がって経済的に見合う程度の防熱層の厚みではタンク 周囲の地盤は必ず凍結することになる。

(3) 図 3, 図 4 は, $50,000 \mathrm{~m}^{3}$ タンクの凍土厚みと ボイルオフの経時変化が防熱の厚みによってどのよう
に変化するかを示したもので, 横軸に時間, 縦軸に凍 土厚みとボイルオフがとってある。d は防熱層の厚み であるが凍土厚み，ボイルオフともに $d$ が増加すると 減少する。しかしながら防熱層が $30 \mathrm{~cm}$ までは減少は 顕著であるが， $45 \mathrm{~cm}$ となっても，それほどの効果が ないことがわかる。このことから $50,000 \mathrm{~m}^{3}$ 程度の夕 ンクでは防熱層の厚みは $30 \mathrm{~cm}$ 前後が望ましいことが

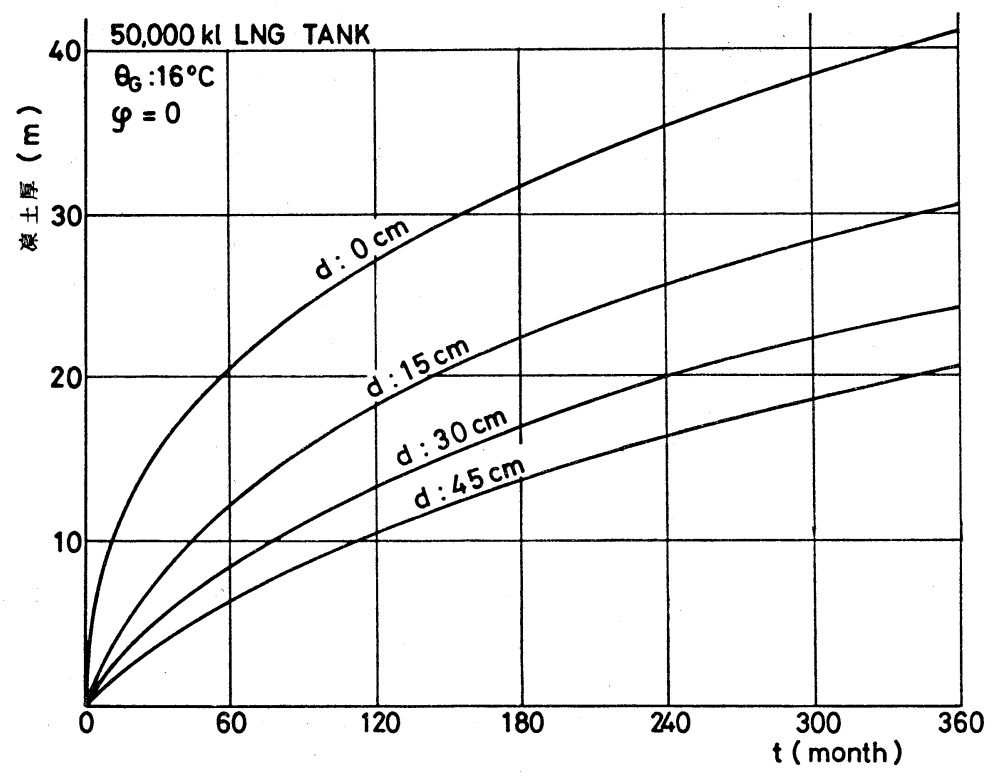

図 3 凍土成長に及ぼす防熱材の効果 (タンク底面方向の凍土厚)

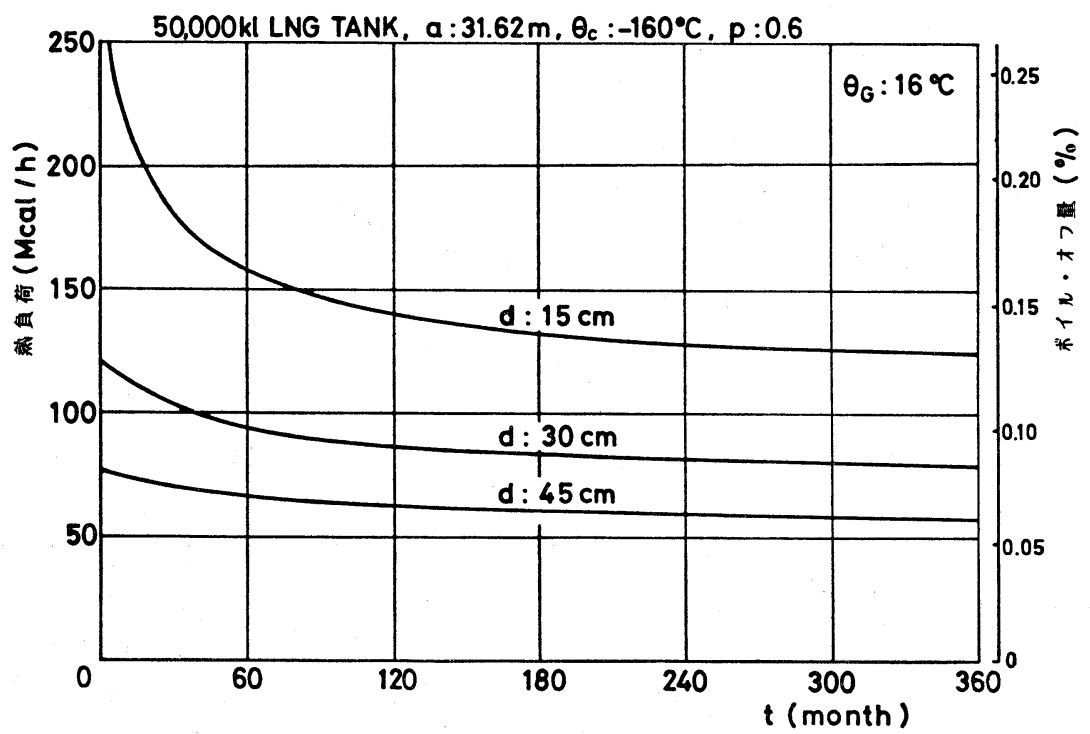

図4 防熱材厚みと熱負荷の関係 
わかる。

(4) 二つ以上のタンクを隣接して建設する場合に, これらタンクの中心線上の凍土が常識的に速やかに成 長することが考えられる。タンク周囲の凍土が隣接す るタンクの凍土と結合する直前には極処的に非常に大 きい土圧増加が生じることが，著者らの人工凍結工法 の経験からわかっているので，タンク中心線上の凍土 の成長速度の推定が，隣接タンクの中心距離を決定す る大きな要素となる。図 5 は $50,000 \mathrm{~m}^{3}$ タンクの水平 方向の凍土厚の経時変化を示したもので，2本の曲線
のうち上のほうの曲線がタンクの干渉によって凍土成 長が促進される上限を示したものである。下のほうは ただ 1 基のタンクがある場合で，両者を比較すると干 渉によってそれほど大きい促進がないことがわかる。 この曲線からタンクの稼働期間を30年とすると，タン クの間が凍土でつながらないための条件はタンクの壁 と壁との間隔が $40 \mathrm{~m}$ 必要であることがわかる。この図 は防熱厚みを $15 \mathrm{~cm}$ として計算したものであるが，も し $30 \mathrm{~cm}$ の防熱厚みが許されるならば，上記 $40 \mathrm{~m} の$ 間

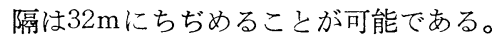

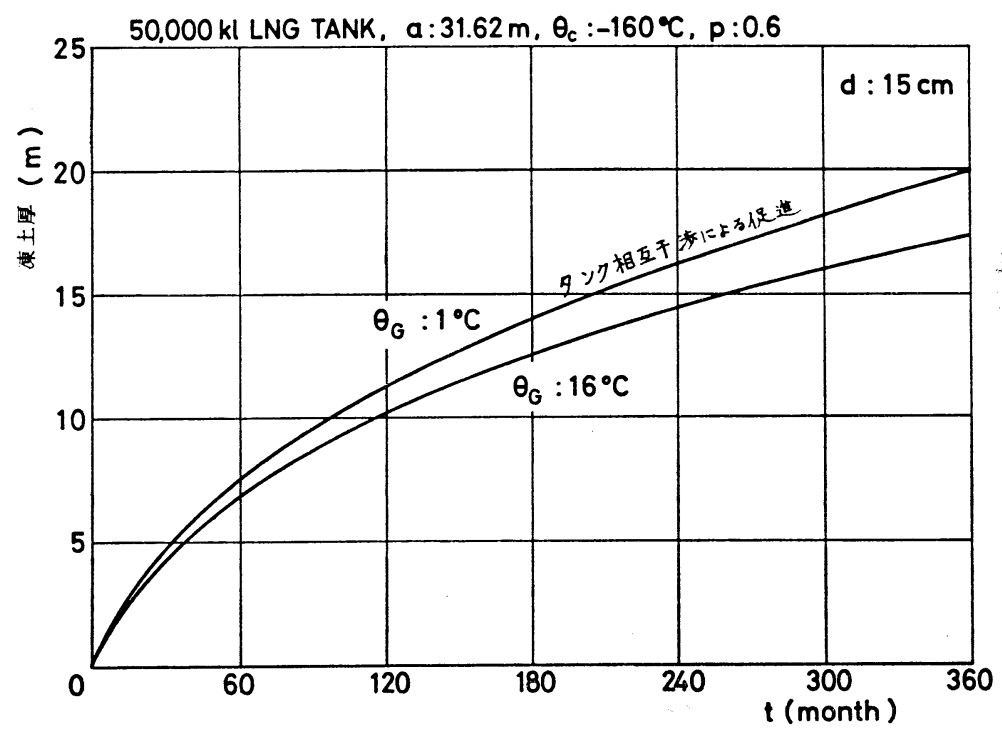

図 5 タンク間相互干渉のある場合 $\left(\theta_{\mathrm{G}}=1^{\circ} \mathrm{C}\right)$ とない場合 $\left(\theta_{\mathrm{G}}=16^{\circ} \mathrm{C}\right)$ における水平方向凍土成長の比較 (GL. - 30m)

(5) 文献 2)，3）は地盤中の地下水の流れと, 地球 の深層から上がってくる地熱を無視しているが, 後者 についてはわが国の温泉地帯に LNG タンクをつくる 可能性はありえないので問題にならないし，前者もキ ヤンベイ基地にあるような, コンクリート軀体も防熱 層もないタンク ${ }^{6)}$ 以外は問題にならない。しかしなが ら，地下タンクの建設時に地盤凍結工法を利用して掘 削を行なう場合には, 地下水流の存在は当然問題にな るので注意しなければならない7。

（6）文献 2)，3）の解析を前出のキャンベイ基地の 地下タンクに適用して計算した結果, この型の地下タ ンクは着想としては非常に興味があるけれども, ボイ ルオフおよび周囲の凍土成長が過大であるために付近 構造物に対する影響が大きいこと，および凍土クラッ クを通じてガスが逃げはじめるとその乾燥効果のため
傷口がますます大きくなるなどの理由で，わが国のよ うな酷しい立地条件のもとでは適当でないことがわか った。

\section{3. 凍土の強度}

前項では, 地下タンクのまわりの土は防熱層がかな り厚くても長年の間には必ず凍結してゆくことを述べ た。まわりの土が凍ると土質によっては次項で述べる ような悪い影響もでるが，砂層，れき層のように凍結 膨張性のない土では強土が増大し，自然災害に対する 地下タンクの安全性はますます増加することになる。 本項では凍結した土のごく一般的特性について述べ る。

\section{(1) 土質の影響}

凍った土は純水の水より強くなり粘土，シルト，砂 碩の順に強くなる。これはコンクリートと同様に土粒 
子の間にある水が凍って土粒子そのものが骨材の役目 をするためである。また上記の順に強度が大きくなる のは，粒子の細かい土ほど土粒間に凍結しきらない水 (不凍水と呼ぶ8) ${ }^{8}$ )が残って，これが強度を弱めるた めである。

\section{(2) 温度の影響}

図 6 , 図 $7^{99}$ はAGA で行なわれた広い温度範囲に わたる凍土の強度試験の結果である。凍結した土はこ のように温度が下がるほど強くなり， $-50^{\circ} \mathrm{C}$ になると

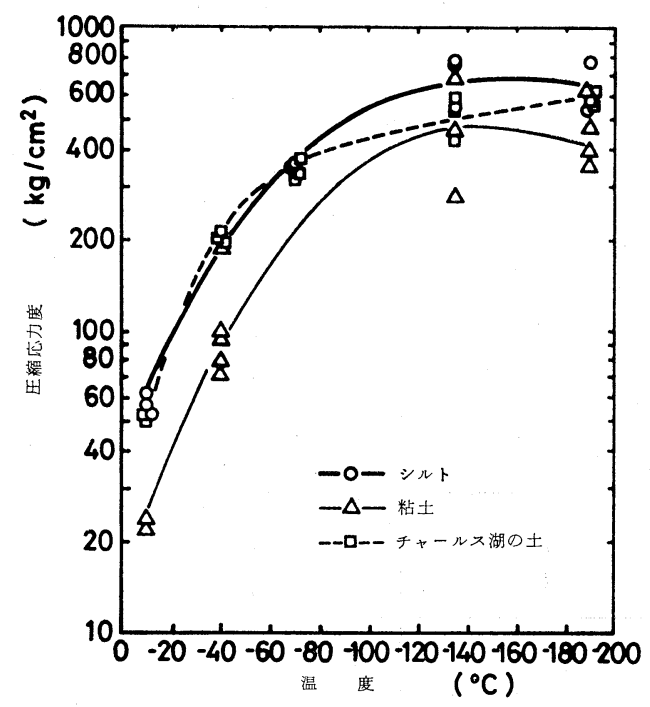

図 6 凍土の圧縮強度 (A. G. A；LNG Information Book, 1965 より)

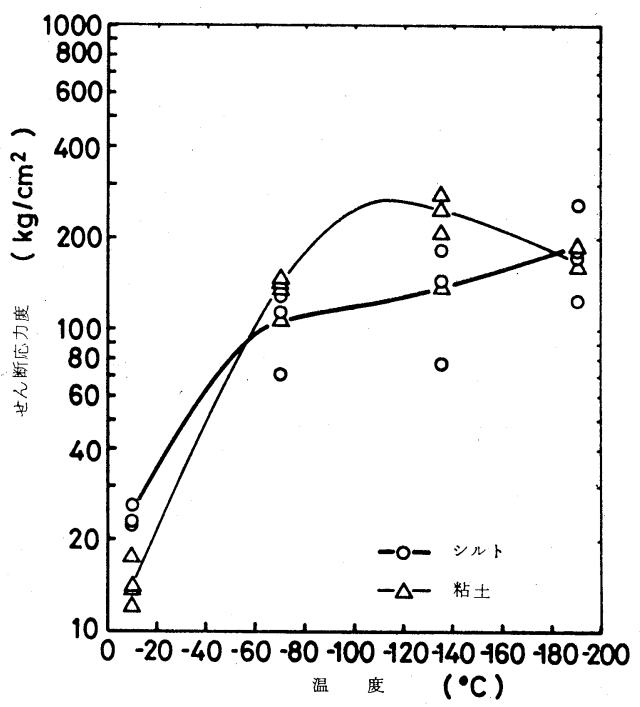

図 7 凍土のせん断強度 (A. G. A； LNG Information Book, 1965 より)
ほぼ常温のコンクリート程度の強度がでることがわか る。しかし, さらに温度が下がり $-100^{\circ} \mathrm{C}$ 程度になる と圧縮, せん断, 強度ともに増加が止まり, それ以後 漸減する傾向になる。

(3) 透 気 性

水で飽和した土が凍結すると土粒子間の空隙は氷で 充嶼され透気性はないように思われるが，水が凍結す るときに水中に溶けこんでいたガス（空気，メタンな ど）が気泡となって残ったり, 水と土粒子の熱膨張係 数に大きい差があるため, 目にみえないクラックが生 じる。したがって凍った土は水を通さないがわずかな がら透気性があるものと考えなければならない。さら に凍結澎張性の強い土では，そのために発生する応力 のためにクラックが発生する機会が多いと考えなけれ ばならない。いったんクラックの中を気化した天然ガ スが走りはじめると, ガスそのものは液化時に完全に 水分が除去されているために, 凍土中の水分は昇華し て，ますます傷口が大きくなる傾向になる。したがっ て地下タンクは, 軀体自身にガスシールの機能をもた せるか，地上タンク同様にメンブレンをつけてガスシ 一ルが完全に行なわれるよう配慮したければならな い。わが国で完成した LNG 地下タンクの第 1 号では メンブレンによってこの機能を果たさせている10)。

\section{4. 地盤の凍結膨張 ${ }^{11}$}

土が凍るといらことは土粒子の間の水が凍ることで ある。周知のように, 水が氷になるときにはその容積 が約 8 \%膨張する。この影響が土の凍るときにも現わ れて，土によっては大きい膨張を示すものもある。こ の現象が地下タンクのクールダウン後の最も大きな問 題を提起寸る原因になるので, 本項では凍結膨張その ものの一般特性について概説する。

\section{(1) 土 質}

凍結膨張はどんな土でも起こるわけではない。20 $\mu$ 以下の細粒成分を含まない土すなわち砂，れき層は凍 結膨張が生じない。土粒子構成に $20 \mu$ 以下の成分が 5 \%以上含まれていると, 必ず膨張が生じるものと考え なければならない。膨張の度合は微粒子成分の含有量 が増大寸るほど大きくなり, 土の分類でいうと粘土, シルト, ローム, と呼ばれる土は凍結膨張性があると 考えなければならない。また一般に腐植士（ピート） と呼ばれる植物性有機質を含んだ土は驚くべき膨張性 を示すことがあるので，とくに注意しなければならな い。

(2) 凍結膨張の方向性

凍結膨張によって生じる力と変位の方向は熱流の方 
向と一致するといわれている。これは自然凍上の研究 者達によって古くから発見されている経験則で, 著者 らの現場経験からは厳密には精確とはいえないが, 凍 結膨張対策をたてる上で非常に重要な法則である。

（3）凍結膨張率と拘束圧の関係

著者らは, 地盤凍結工法における凍上対策の必要性 から拘束圧の増加によって, 凍結膨張率が減少する法 則性を見つけるために, 特殊の開放型凍上実験装置を 開発し ${ }^{12)}$ ，これによって種々の土について数多くの実 験をくり返し, 以下に述べる四つの法則性を発見し た。まず第 1 は凍結膨張率 $\xi$ と拘束圧 $\sigma$ とはほぼ逆比 例関係にあり，

$$
\xi=\xi_{0}+\frac{c}{\sigma}\left(\xi_{0}, c: \text { 定数 }\right)
$$

で表わされることである。実験結果と上式を比較する と図8のようになる。

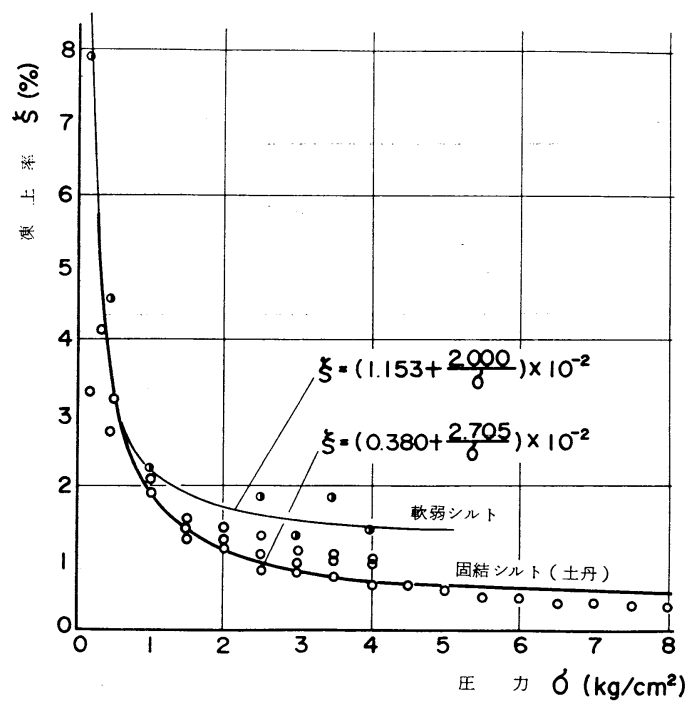

図 8 凍結試験による $\boldsymbol{\xi}-\boldsymbol{p}$ 曲線の決定（軟弱シ ルトと硬質シルトの例）

ここで興味あることは，(1)式の拘束圧 $\sigma$ が大きくな るにつれて凍結膨張率 $\xi$ は漸減するが， $\xi_{0}$ だけが残 ることである。この残留膨張率は，土粒子のまわりの 不凍水が温度の低下とともに凍結する結果によるもの と考えられ，細粒成分の多い土ほど大きくなる傾向に ある。

(4) 間隙水収支

凍結進行中の間隙水収支に関しては，拘束圧力 $\sigma$ が 小さいときは，自然凍上の場合にすでに発見されてい るように周囲の水を吸引しながら膨張するが，拘束圧
が大きいときには排水しながら膨張する。一般に吸水 と排水の限界は， $\sigma$ が $0.5 \mathrm{~kg} / \mathrm{cm}^{2}$ と $2 \mathrm{~kg} / \mathrm{cm}^{2}$ の間 にあり, 細粒分や有機質の多以土ほど限界圧力は大き くなる傾向にある ${ }^{13)}$ 。

(5) 凍結速度と凍結膨張率の関係

拘束圧 $\sigma$ が比較的小さい場合については, 凍結膨張 率は凍結進行速度が小さくなるにつれて大きくなる傾 向がみられる ${ }^{14)}$ 。しかしながら拘束圧が大きくなると どうなるかについては, 実験を進めていないので目下 は不明である。

(6) 間隙水圧と凍結膨張率の関係

凍結進行中の凍土面に接する土が凍結面を押す力 は，一般に土圧と呼ばれている。土圧 $\sigma$ は土粒子相互 の押し合う力 $\sigma_{e}$ (これを有効応力という）と間隙水 圧 $p_{w}$ の和で表わされる。すなわち,

$$
\sigma=\sigma_{e}+p_{w}
$$

である。著者らは間隙水圧 $p_{w}$ の影響を見るために, 土の有効応力 $\sigma_{e}$ を一定にして間隙水圧 $p_{w}$ を変化さ せて実験を行ない, 凍結膨張率は有効応力だけによっ て増減し間隙水圧には無関係であることを発見した。 したがって(1)式は間隙水圧が 0 でないときは次のよう に修正すべきことがわかった。

$$
\xi=\xi_{0}+\frac{c}{\sigma_{e}}
$$

\section{5. 凍結膨張によって起こってくる問題点}

2 項で述べたように, 地下タンク周辺の土は時間の 経過とともに必ず凍結し, その凍結範囲もかなり正確 に推定できるようになった。また 4 項では土が凍結す るときに起こる凍結膨張の法則性も, ほぼその輪廓が つかめ, とくに拘束圧力と凍結膨張率は簡明な実験式 (1)であらわされることが明らかになった。本項ではこ の凍結澎張がタンク自身および周辺地盤にどんな影響 を及ぼすかを概説する。

(1) タンク底方向からの揚圧力の増加

なんらかの方法でタンク構築が完成しクールダウン に大った時点では, タンクの底は図 9 に示すように, 上 向きの有効応力 $\sigma_{e}$ と水圧 $p_{w}$ を受けて, これらの力 に耐える状態で平衡を保っている。この力のうち $p w$ は場所的に一様で容易に実測できるが， $\sigma_{e}$ について は掘削を行ならときに採用した工法によって大幅に変 化する可能性があり, 一般論として論じえない不確定 性がある。この状態から出発して, 底面下に凍土が成 長して, しかもその場所の土が凍結膨張性の土であれ ば当然膨張による過剩の圧力 $\sigma_{f}$ が付加される。凍土 の厚みが十分厚くなってこの過剩圧力に耐えられる状 


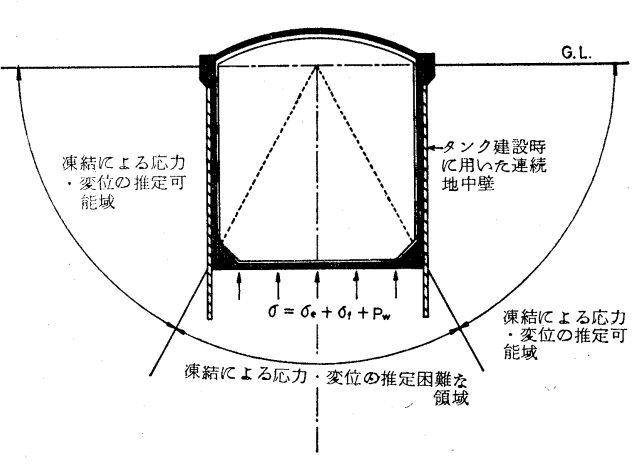

図 9 タンク周辺の地盤内応 カ変位推定可能範囲

態になれば問題はないが, そのような状態になるまで の期間は, この過剩圧力をも含めた揚圧力,

$$
\sigma=\sigma_{e}+p_{w}+\sigma_{f}
$$

に対抗できるようにタンクの底の構造を決定しなけれ ばならない。地下タンクが一様な軟弱地盤中に建設さ れる場合には，次項で述べるように $\sigma_{f}$ は $\sigma_{e}$ の 0.1 〜0.2 倍程度に止まりそれほど問題にならないが, 硬 質でしかも膨張性の地艋の場合には $\sigma_{f}$ は $\sigma_{e}$ の数倍 または10数倍も大きくなる可能性がある。そのうえ， $\sigma_{f}$ が $\sigma_{e}$ の関数になるといら厄介な条件があるので 実験による以外に推定の方法がない。したがって現在 の時点では, タンクの底付近に凍結膨張性の土がある 場合には, 予めその部分を凍結しておいてタンクを建 設するか, または底部の防熱層の強化, 揚水による $p w$ の低下や, さらに積極的に加熱して底方向の土を凍結 させないといら配慮が必要であろら4。

(2) タンク周壁回りの土圧と変位の問題

タンク底方向の問題が非常に複雑であることは上記 の通りであるが，タンク周壁回りの問題は比較的簡単 で理論解析にかかる可能性をもっている。著者らは, この問題をいくつかの仮定を設定したうえで一応理論 的に解くことに成功した ${ }^{15)}$ 。理論展開は原論文にゆず り，本項では LNG 地下タンクに焦点をあわせた結論 だけを述べることにする。

(a) 最大応力と最大変位

タンク周壁の外側方向に成長する凍土の凍結膨張に よって, 凍土の外側の未凍結土中の水平土圧は増加 し, 土はタンクの半径方向に押し出された形で変位を 起こす。これらの応力, 変位は凍土と末凍結土との境 界で最大となり, 半径方向に遠ざかるほど減少する。 減少度合は, 応力の場合はタンク中心からの半径の 2 乗に反比例し, 変位は半径に反比例する。したがって 未凍結土中の水平変位は，かなり遠くまで影響がある
と考えなければならない。

\section{(b) 土質の影響}

図10は, この方法で計算した $50,000 \mathrm{~m}^{3}$ の地下タン ク (防熱厚 $15 \mathrm{~cm}$ ) のまわりに発生する最大水平応力 と最大変位の経時変化を示したものである。横軸に時 間, 縦軸に応力と変位がとってある。比較のために, タンクが一様な軟弱シルトの場合と一様な硬質粘土の 場合を示したものである。両者を比較すると，軟弱地 盤の場合は水平応力の変化はほとんどなく, 水平変位 が大きく現われる。したがって, タンク周辺に永久構 造物があるときには基礎の変位に注意が払われなけれ ばならない。一方, 硬質粘土地盤の場合は変位は軟弱 地盤の場合の半分以下であるが, 応力増加が顕著であ るため最初の数年間はタンク軀体をしめつける力が非 常に大きくなる。

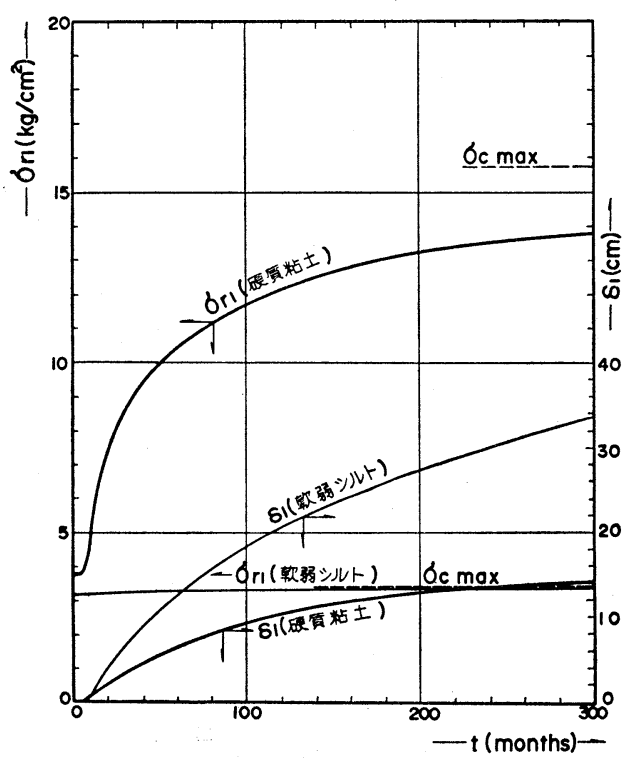

図10 50,000 kl タンク周辺の未凍結土内の半径 方向主応力 $\left(\sigma_{\mathbf{r}_{1}}\right)$ と変位 $\left(\sigma_{1}\right)$ の経時変化 (円筒状凍土の場合)

(c) 塑性領 域

凍結領域外側地盤には凍結膨張による応力増加のた めに, その弹性的構造が破壊された塑性領域が発生す る。しかし, この領域の応力増加と変位に対する寄与 はそれほど大きくないので, 実用的には, 凍結領域外 側の未凍結地盤の挙動は弾性体として計算しても大き い誤差は生じない。

(3) 垂直変位

地下タンク周囲の凍結膨張の影響は当然地表面にも 
現われ，地表面がタンクを中心に陣笠状に持ち上がっ た形で現われる。これに対する予測方法は，著者らの 地盤凍結の経験から導いた半理論・半実験式がある ${ }^{16)} 。$ この方法は仮定が大胆すぎるので誤差は土50\%程度と 非常に大きいが，付近に存在する重要構造物に対する 影響を検討するためには非常に便利な方法である。図 11は，この方法で計算した $50,000 \mathrm{~m}^{3}$ 程度のタンクの 地表面の変位の一例である。この例では, クールダウ ン後30年で地表の持上がりは $45 \mathrm{~cm}$ 程度で, 影響範囲 はタンク半径の 3 倍程度にまで及ぶことがわかる。

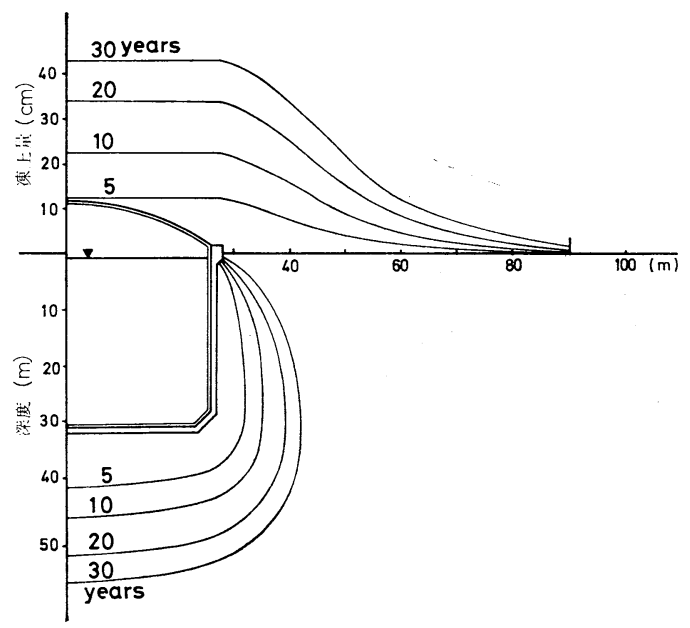

図11 $50,000 \mathrm{k} l$ LNG 地下タンクによる地表面の 凍上 (断熱厚 $15 \mathrm{~cm}, \theta_{\mathrm{G}}: 16^{\circ} \mathrm{C}, \theta_{\mathrm{C}}:-160$ ${ }^{\circ} \mathrm{C}, \mathrm{P}: 0.6$ )

\section{6. 凍結膨張対策}

以上，地下タンクの問題点を列挙したが，これらは いずれも地下タンク周辺の土が凍結膨張を起こすこと によって発生する問題である。したがって凍結膨張の 起こらない地盤すなわち砂またはれき地盤中にタンク をつくることができるならば全く問題は起こらない。 しかし，現在の日本の大都市周辺の海岸でこのような 理想的な地盤を選定することは全く不可能である。し たがって LNG 地下タンクヤードは程度の差はあって も凍結膨張性があると考えなければならない。他方, 本論文ではふれなかったが，タンク建設時に直径の大 きい，しかも深い穴を安全に掘さくしなければならな いという大きな問題もある。

著者らが提案したい凍結膨張対策は，この建設時の 問題解決もかねてタンクをつくろうとする周囲地盤を 予め凍結してから，この凍土壁を頼りにして掘削を行
ない，その中にタンク軀体を建設することである。そ うすれば，この凍結のために発生した応力や変位は掘 削時にある程度緩和し，クールダウン後の発生応力と 変位は小さくなる15) うえ, 予め凍結してある土が応力 増加に十分対抗するので, 凍結膨張の問題, とくに変 位に対しては完全には解決しないけれども，他の問題 点は予めつくる凍土厚みを適当に選ぶことによって， ほぼ完全に解決することができるであろう。

\section{7. 結 論}

自然災害に対して卓越した安全性をむつ LNG 地下 タンクも，このように見てくると，かなり多くの問題 点を包蔵していることがわかる。これらの問題点に対 し未だ確立した対策はないが，一つひとつ吟味してみ ると，現在のわが国の技術をもってすれば克服不可能 なものはないように感じられる。しかしながら総合的 にでき上った地下タンクの価格は, 現在の地上 2 重殻 型式のタンクに比較すれば， $50,000 \mathrm{~m}^{3}$ 程度を比較す るとかなり高価になるよらである。したがって地下タ ンクとしては，1基の大きさを $100,000 \mathrm{~m}^{3}$ 以上に大 きくすることもコスト引下げ方策の一つとして有効な 方法であるが，さらに根本的には，これら問題点の一 つひとつを安全性と経済性に見合った形で解決してい くことが,われわれ技術者の英知であり使命であろら。

\section{文献}

1) 安田火災海上保険(株), 防災ニュース, 特報 No. 6 ，（昭和 45 年）

2) 高志, 住吉, 液化低温ガス貯蔵用地下タンク周囲 の地盤の凍結について，冷凍，44，910（1969）

3）高志，液化低温ガス貯蔵用地下タンク周囲の地盤 の凍結について II，冷凍，47，(536)，(1972)

4) B. E. Eakin, et al., Belowground Storage of Liquefied Natural Gas in Prestressed Concrete Tanks, American Gas Association Inc. Institute of Gas Technology Technical Report, No. 8

5) 秋田他, 低温地下タンクの施工方法と熱的諸問 題, 土木学会論文報告集, 第 199 号 (1972)

6) J. A. Ward \& P. C. Egan, Experience with Frozen Inground Storage Units for Liquefied Natural Gas-Canvey Island (U.K.), Conference on LNG, its production handling and use., London, 25, 28-Mar., (1969) Session 5; storage, p. $1 \sim 24$

7）高志，凍結管列の涷結結合に対する地下水流の影 響について，土木学会論文報告集，第 161 号（19 69) 
8) P. J. Williams, Unfrozen Water Content of Frozen Soils and Soil Moisture Suction. Geotechnic, Oslo., (1964)

9) LNG Information Book, May 1965, Prepared by LNG Task group of the manufactured gas production Committee AGA

1.0）野尻, セグメント式 LNG 地下タンク, 石油学会 誌， 14，(2)，40

11）高志, 凍上, 沈下と施工対策, 施工技術, 3, (3), 12 (1970)

12）高志，住吉，上載荷重がある場合の開放型凍上に おける凍上量の増減について, 土木学会第2 4 回年
次学術講演会講演概要, III-120, (1969)

13）高志, 益田, 拘束圧下に抢ける土の凍上量と間隙 水の移動について, 雪水(雪水学会誌), $33,(3)$, (1971)

14）高志, 益田, 凍結速度が土の凍上現象に及ぼす効 果について, 日本雪水学会昭和 46 年度秋季大会講 演予稿集, 30, (1971)

15）高志, 凍結膨張による末凍結領域内の土圧と変位 の経時変化, 土木学会論文報告集, 第 200 号, p. 49 (1972)

16）高志, 戸部, 凍上変位計算法, 土木学会第25回年 次学術講演会予稿集, III, p. 327 (1970)

\title{
On the Problems Caused by Ferrzing soil Around Underground Storage Tank for Liquefied Natural Gas
}

\author{
T. Takashi \\ (Seiken Reiki Co. Ltd.)
}

SYNOPSIS:- In this paper the problems and the countermeasures occurred to underground storage tank for liquefied natural gas under operation are described.

Author firstly explains that soil around underground storage tank for LNG freeze necessarily after cool-down, further gives an outline of the rules of expansion of freezing soil, secondry explains the results of theoretical analysis for the pressure and the displacement in soil originated from this expansion, and in conclusion proposes that it is the most effective method for solving the problems to freeze soil around underground storage tank before excavation. 